Indonesian Journal of EFL and Linguistics

Vol. 2 No. 1, 2017

eISSN: 2503-4197, pISSN: 2527-5070

www. indonesian-efl-journal.org

\title{
The Effect of Teaching Summarization Strategies on Reading Comprehension of Science and Humanities Iranian High School Students
}

\author{
Azam Sadat Pourhosseini Maybodi \\ Department of English, Islamic Azad University, Maybod Branch, Yazd, Iran \\ e-mail: pourhosseini1350@gmail.com \\ Ashraf Haji Maibodi \\ Department of English, Islamic Azad University, Maybod Branch, Yazd, Iran \\ e-mail: amaibodi2014@gmail.com
}

\begin{abstract}
:
This study investigated the effect of teaching summarization strategies on the reading comprehension of English as Foreign Language (EFL) high school students. To this end, 80 high-school students from science and humanities sections were divided to two groups of 40 each. Two reading comprehension tests were developed and administered as pre-test and post-test. The obtained data that was analyzed using SPSS software showed that EFL learners in both groups showed significantly more improvement in their reading comprehension from the pre-test to the post-test. However, the numerical findings obtained from the paired samples $t$ test showed that students in the science group outperformed those who were in the humanity group and their scores seemed to be more statistically significant. The major pedagogical implication of this study is that summarization strategy can help to improve the reading comprehension of EFL high school students in Iran.
\end{abstract}

Keywords: EFL learners; Reading comprehension, Summarization strategy.

\section{INTRODUCTION}

Reading and learning to read, according to Wallace (1992), is "a social, interactive process as well as a personal activity (p.17)" In fact, in the age of the internet and 
information revolution, reading retains its importance as an essential skill for learners of any language (Alderson, 2000). Although reading comprehension is sometimes overlooked, it is clear that reading for comprehension is the primary purpose and raising student's awareness to the main ideas in a text and exploring the organization of a text are essential for good comprehension (Richards \& Renandya, 2001). It is generally agreed that well-developed reading comprehension ability is the key to students' academic success. This comprehension ability is not a passive state which one possesses, but it is an active mental process which needs to be nurtured and improved (Karbalaei \& Rajyashree, 2010). McNamara (2007) believed that comprehension is the ability to go beyond the words, to understand the ideas in a text and the relationships that exist between those ideas. However, in practice, it is difficult for many beginner readers to comprehend what they read. Often, they face problems even with the typical question and answer format that is provided after they read a passage. Research (Dole, Brown, \& Trathen, 1996; Janzen, 2003; Karbalaei \& Rajyashree, 2010; Khoshsima \& Rezaeian Tiyar, 2014; Pakzadian \& Eslami Rasekh, 2012; Nurhayati, 2014; Roohani, et al., 2015; Deshpande, 2016; Teng. 2016; Damayanti, 2017) has shown that together with direct instructions when students are taught reading strategies this will improve not only their comprehension of the reading passage but also their performances on the tests. There is no doubt that, according to Nation and Angell (2006), "The ultimate goal of reading is not to read isolated words, but to understand what has been read" (p. 77). Therefore, if reading for meaning is the goal for both students and teachers, more emphasis should be placed on the teaching of successful reading comprehension strategies.

Notably, since the past decades, there has been sustained interest in promoting reading comprehension ability as a significant and viable means of language development for foreign language (FL) learners (Susser \& Robb, 1990). According to Susser and Robb (1990), "reading in English as a foreign language (EFL) has been greatly emphasized in traditional FL teaching contexts, and until today, EFL reading is the core of language instruction in many countries" (p.17). Today, this instruction focuses on teaching readers rather than teaching texts (Davis, 2010). To be more specific, teachers now teach reading skills and strategies to understand some elements related to the process like content, textual features, rhetorical elements, and cultural background. In fact, reading strategies are more and more welcomed by the teachers. Although there are a small number of studies investigating the application of such strategies for other Asian EFL learners (Madkhali, 2005; Mushait, 2004; Al-Nujaidi, 2003; Al-Seweed, 2000), there is an unclear picture about the most popular uses of reading strategies by Iranian EFL learners in high schools. At present, few studies have been conducted on the effectiveness of reading strategies on Iranian EFL learners' reading comprehension. The scarcity of such studies does not permit the creation of any firm conclusions or generalizations about the effectiveness or success of teaching reading strategies in Iranian context.

Taking the above perceptions and the gap that exists in the Iranian EFL context, the overall aim of this study was to explore the effect of summarization on reading 
comprehension of Iranian science and humanities high school students. It also tried to provide a comparison of the learners' performances in the two educational groups and about the application of summarization strategy in L2 reading comprehension context. Since very little research has been reported so far considering this area, the primary goal of this study was to find the effect of this strategy on learners' reading comprehension and proficiency level, as a whole. This study was prompted by the following research questions:

1. To what extent do teaching summarization strategies affect reading comprehension of Iranian high school (science and humanities) students?

2. Do teaching summarization strategies increase proficiency level of science Iranian high school students?

3. Do teaching summarization strategies increase proficiency level of humanities Iranian high school students?

\section{LITERATURE REVIEW}

Reading as an important skill is the fastest and simplest way to raise people's educational level (Hung \& Tzeng, 2000). It is a process of how information is processed from the text into meanings, starting with the information from the text, and ending with what the reader gains. Reading comprehension is a complex process that has been conceptualized and explained in a countless number of ways. The literature on reading provides several definitions of reading strategies. According to Garner (1987), reading strategies are mainly deliberate, planned activities used by active readers, to remedy apparent cognitive failure. Summarization is a strategy that serves two functions. It encourages the reader to concentrate on the main idea in the text instead of details, and it allows the reader to process the text by excluding irrelevant information (Kamil, 2004). Kamil stressed that only few students are taught explicitly to summarize what they read and, consequently, only these students develop the necessary skills to prepare good summaries. Moreover, Kamil (2004) also pointed out that summarizing not only improves comprehension but that this improvement is transferable to other situations.

Over the past three decades, numerous studies have detailed the role of learners' strategies in a variety of L2 domains. For example, Al-Seweed (2000) investigated the effects of proficiency and training on the word-solving strategies of Arab EFL Readers. The findings suggested that the students used a range of word-solving strategies: contextual and morphological guessing, appealing for assistance (i.e. asking someone, using the dictionary and asking each other), and skipping, both before and after WSS instruction. The results demonstrated that both high and low proficiency level students used only immediate contextual clues in guessing. Chang (2000) investigated the relationship between four metacognitive factors: subjects' perception about their reading abilities, about repair strategies, about effective strategies, and about what causes them difficulty and reading ability in L1 and L2. In addition, Hsu (2000) collected 315 students' questionnaires to examine the reading comprehension difficulties encountered by junior high school students in Taiwan. This investigation focused on reading comprehension difficulties they encountered

Indonesian Journal of EFL and Linguistics, Vol. 2 (1), 2017 
and reading strategies they used at the three stages (pre-reading, while reading, and post-reading).

In a more comprehensive study, Al-Nujaidi (2003) attempted to find out the relationship between vocabulary size, reading strategies, and reading comprehension of EFL learners in Saudi Arabia. This study examined how certain learner variables, such as gender and the amount of extensive reading, may affect this relationship. The results showed that extensive reading was found to be an unpopular activity among EFL learners in Saudi Arabia. Moreover, significant gender differences favoring females were found in the participants' performance on the two tests and their reports of reading strategies use.

Madkhali (2005) in an article named "The effects of training ESL Saudi female students on some reading strategies" investigated the effectiveness of teaching four reading strategies on EFL Saudi female students' reading comprehension and on their reported use of these strategies. This study aimed at investigating the impact of teaching global and problem-solving strategies on preparatory-level students' reading comprehension. The results obtained led to three findings. Firstly, the two training groups (global and problem solving) experienced only non-significant improvement in their post-reading comprehension when compared with the control group. This could suggest that reading strategy training did not significantly improve their reading comprehension. Secondly, there was no significant difference between the two treatment groups in their gain in reading comprehension. Thirdly, there were various results regarding students' perception of using the strategies they were taught. Students mostly showed a decrease in their perception of using strategies either significantly or non-significantly except for two strategies which were using context clues and prediction.

Sheorey, Kamimura and Freiermuth (2008) studied the reading strategies of 237 Japanese students studying technical English in a Japanese University. Students were asked to rate their reading ability on a scale from one to six, from which they were divided into high and low groups. The results showed significant differences between the high and low groups on nine individual strategies. In addition, on $80 \%$ of the strategies, the high group used more strategies than the low group. Malcolm (2009) conducted a survey of reading strategy use with 160 first year and fourth year medical students in Bahrain in order to compare perceived reading strategy use of readers at varying English proficiency levels and years of study. The study found significant differences in reported use of metacognitive strategies in general and in translating strategies from English to Arabic with low English proficiency and the first year reported more translation than the upper-year students report. In addition, Munsakorn (2012) investigated the awareness of reading comprehension strategies among Taiwanese students. The participants were from science and social science departments at Bangkok University. With respect to overall records of reading strategies, the Taiwanese students showed a high-level awareness of overall reading strategies. Another study (Bagheri, 2012) has been conducted on the effectiveness of language learning strategy use. The study revealed that intermediate level students reported more use of learning strategies than beginning and advanced students and 
that more strategic language learner improved faster along the proficiency continuum than the less strategic ones.

\section{RESEARCH METHODOLOGY}

\subsection{Participants}

This study was conducted using two groups of 80 female pre-university students in a pre-university center in Ardakan, Yazd. They ranged in age from 17 to 19 and had already studied English for 6 years at school. Due to the regulations of the center that imposed limitations on selecting the participants, the selection of the participants of the study was carried out based on convenient sampling procedure. The point worth noting is that each group contained more than 40 candidates, but since some of the students were of a low or very high proficiency level than the others, they were omitted as outliers. In order to establish the homogeneity of the two groups, demographic information taken from the participants regarding their linguistic background and residence in English speaking countries showed that none of the students had been to a foreign language country and they were all Persian speaking students.

\subsection{Materials}

In order to gather the intended data, two reading proficiency tests (pre-test and posttest) were employed to assess reading comprehension of participants in both humanity and science groups.

To establish the content validity of the tests, four articles selected for each test, were adapted from "Reading for TOEFL Test" (Broukal, 2002). The pretest was conducted to measure the participants reading comprehension level before treatment. In addition, the aim of the reading comprehension post-test was to analyze if the students had made any improvement after the reading strategy instruction. Both tests consisted of 20 multiple-choice items. Attempts were made to make the pre-test and post-test to have similar patterns of question types. The items consisted of detailed questions, inference questions, authors' purpose questions, writing pattern questions, and some questions about the main ideas of the texts. The reliability index obtained for the pre-test was 0.73 , and 0.79 for the post-test.

\subsection{Procedure}

As already mentioned, in order to select the intended participants, two intact classes in a pre-university center in central Iran, Ardakan, Yazd was taken into consideration. The homogeneity of these students was explored using their final exam scores. The students with very high or low scores were marked. In fact, all the students in the intended classes were tested, but the exam sheets of the outliers were not scored.

Next, reading comprehension tests were developed. Before carrying out the main research, a pilot test was conducted to find out the flaws and shortcomings of the tests designed. In order to modify the tests the tasks were administered to six EFL learners (three students from humanity courses and three from science courses).

Indonesian Journal of EFL and Linguistics, Vol. 2 (1), 2017 
After the modifications made to the tests, they were administered as reading comprehension pre-tests to the participants in both the groups. Then the participants in both humanity and science groups were proposed to the intended treatments. The treatment was concerned with the use of summarization strategy in reading comprehension sessions. During the sessions (10 sessions) which were devoted to the application of the treatment, the teacher would read the texts paragraph by paragraph. At the end of one or two paragraphs, she, herself, would provide the students with the summary and mention the key points about the strategy. After that, she would ask the students to summarize the other paragraphs and even write the summaries. At the end of the text, there were some of reading comprehension questions, which could be answered easily based on the written summaries. During the treatment sessions, the participants, in both groups, got fully acquainted with the summarization strategy and improved their reading comprehension ability. One week after the provision of the last text and summary, a post-test was given to the participants in both humanity and science groups. The test, as mentioned above, was intended to measure the participants' improvement in reading comprehension of Iranian EFL learners.

\section{FINDINGS}

In order to find a plausible answer for the research questions, the performances of the humanity and the science groups in the pretest were compared conducting an independent-samples t-test.

Table 4.1: Descriptive Statistics of Humanity and Science Groups in Pre-test

\begin{tabular}{|l|l|l|l|l|l|}
\hline & \multicolumn{1}{|c|}{ Group } & N & Mean & $\begin{array}{c}\text { Std. } \\
\text { Deviation }\end{array}$ & $\begin{array}{c}\text { Std. Error } \\
\text { Mean }\end{array}$ \\
\hline pretest & humanities & 40 & 9.0750 & 2.34671 & .37105 \\
\cline { 2 - 6 } & Sciences & 40 & 9.3250 & 2.06792 & .32697 \\
\hline
\end{tabular}

Table 4.2 shows the independent samples t-test for the pre-test scores and the significance of this trivial difference between the two groups in pre-test.

Table 4.2: Independent Samples T-test for Pre-Test Scores

\begin{tabular}{|c|c|c|c|c|c|c|c|c|c|c|}
\hline & & \multicolumn{2}{|c|}{$\begin{array}{c}\text { Levene's } \\
\text { Test for } \\
\text { Equality } \\
\text { of } \\
\text { Variances } \\
\end{array}$} & \multicolumn{7}{|c|}{ t-test for Equality of Means } \\
\hline & & \multirow[t]{2}{*}{$\mathrm{F}$} & \multirow[t]{2}{*}{ Sig. } & \multirow[t]{2}{*}{$\mathbf{t}$} & \multirow[t]{2}{*}{ df } & \multirow{2}{*}{$\begin{array}{l}\text { Sig. } \\
(2- \\
\text { taile } \\
\text { d) }\end{array}$} & \multirow[t]{2}{*}{$\begin{array}{l}\text { Mean } \\
\text { Differe } \\
\text { nce }\end{array}$} & \multirow{2}{*}{$\begin{array}{l}\text { Std. } \\
\text { Error } \\
\text { Differ } \\
\text { ence }\end{array}$} & \multicolumn{2}{|c|}{$\begin{array}{l}95 \% \text { Confidence } \\
\text { Interval of the } \\
\text { Difference }\end{array}$} \\
\hline & & & & & & & & & Lower & Upper \\
\hline \multirow[t]{2}{*}{$\begin{array}{l}\text { pre } \\
\text { test }\end{array}$} & $\begin{array}{l}\text { Equal } \\
\text { variances } \\
\text { assumed } \\
\end{array}$ & .664 & .418 & -.506 & 78 & .615 & -.25000 & .49455 & -1.2345 & .73458 \\
\hline & $\begin{array}{l}\text { Equal } \\
\text { variances not } \\
\text { assumed }\end{array}$ & & & -.506 & 76.78 & .615 & -.25000 & .49455 & -1.2348 & .73483 \\
\hline
\end{tabular}


As it is apparent, there was no significant difference in the pretest scores of the science group $(\mathrm{M}=9.075, \mathrm{SD}=2.346)$ and the humanity group $(\mathrm{M}=9.325, \mathrm{SD}=$ $2.067), \mathrm{t}(78)=0.506, \mathrm{p}=0.615$ (two-tailed). The magnitude of the difference in the means (mean difference $=0.250$ ) was very small (eta squared $=0.019$ ).

Then, in order to demonstrate the performance of the two groups a paired sample ttest was conducted. According to the objectives proposed before, this analysis can reveal the effect of summarization on reading comprehension of Iranian EFL learners. Table 4.3 reveals the descriptive statistics of the science group.

Table 4.3: Descriptive Statistics of Science Group

\begin{tabular}{|l|l|l|l|l|l|}
\hline & & \multicolumn{1}{|c|}{ Mean } & \multicolumn{1}{|c|}{$\mathbf{N}$} & $\begin{array}{c}\text { Std. } \\
\text { Deviation }\end{array}$ & $\begin{array}{c}\text { Std. Error } \\
\text { Mean }\end{array}$ \\
\hline PPair & pretest & 9.3250 & 40 & 2.06792 & .32697 \\
\cline { 2 - 6 } & posttest & 14.2750 & 40 & 2.64078 & .41754 \\
\hline
\end{tabular}

Table 4.3 shows that the participants in science group had an improvement in their scores from pre-test $(\mathrm{M}=9.325, \mathrm{SD}=2.067)$ to post-test $(\mathrm{M}=14.275, \mathrm{SD}=2.640)$. Table 4.4 shows the results of the paired samples t-test for identifying the significance of the difference between pre-test and post-test scores of the science group.

Table 4.4: Paired Sample T-test for the Science Group

\begin{tabular}{|c|c|c|c|c|c|c|c|c|c|}
\hline & & \multicolumn{5}{|c|}{ Paired Differences } & \multirow[t]{3}{*}{$\mathbf{t}$} & \multirow[t]{3}{*}{ df } & \multirow{3}{*}{$\begin{array}{l}\text { Sig. } \\
(2- \\
\text { tailed } \\
\text { ) }\end{array}$} \\
\hline & & \multirow[t]{2}{*}{ Mean } & \multirow{2}{*}{$\begin{array}{c}\text { Std. } \\
\text { Deviatio } \\
\mathbf{n}\end{array}$} & \multirow{2}{*}{$\begin{array}{l}\text { Std. } \\
\text { Error } \\
\text { Mean }\end{array}$} & \multicolumn{2}{|c|}{$\begin{array}{l}\text { 95\% Confidence } \\
\text { Interval of the } \\
\text { Difference }\end{array}$} & & & \\
\hline & & & & & Lower & Upper & & & \\
\hline Pair 1 & $\begin{array}{l}\text { pretest } \\
- \\
\text { posttes } \\
\text { t }\end{array}$ & -4.95 & 1.76795 & .27954 & -5.51542 & -4.38458 & -17.708 & 39 & .000 \\
\hline
\end{tabular}

The numerical findings obtained from conducting the paired samples t-test, shows that there was difference in the pre- and post-test scores in science group. Results show that the scores were statistically significant from the pretest $(\mathrm{M}=9.325, \mathrm{SD}=$ $2.067)$ to the post-test $(\mathrm{M}=14.275, \mathrm{SD}=2.640), \mathrm{t}(39)=17.708, \mathrm{p} \leq 0005$. The mean increase of the obtained scores was 4.950 with a $95 \%$ confidence interval ranging from 5.515 to 4.384 . The eta squared statistic (0.63) indicated a large effect size.

In order to study the effect of summarization strategy on reading comprehension of Iranian EFL learners in the humanities group, another paired samples t-test was conducted. Table 4.3 shows the paired samples t-test results for identifying the significance of the difference between pre-test and post-test scores of the humanity group. 
Table 4.5: Paired Sample T-Test for Humanity Group

\begin{tabular}{|c|c|c|c|c|c|c|c|c|c|}
\hline & & \multicolumn{5}{|c|}{ Paired Differences } & \multirow[t]{3}{*}{$\mathbf{t}$} & \multirow[t]{3}{*}{ df } & \multirow{3}{*}{$\begin{array}{l}\text { Sig. } \\
(2- \\
\text { tailed })\end{array}$} \\
\hline & & \multirow[t]{2}{*}{ Mean } & \multirow[t]{2}{*}{$\begin{array}{c}\text { Std. } \\
\text { Deviation }\end{array}$} & \multirow{2}{*}{$\begin{array}{l}\text { Std. } \\
\text { Error } \\
\text { Mean }\end{array}$} & \multicolumn{2}{|c|}{$\begin{array}{l}\text { 95\% Confidence } \\
\text { Interval of the } \\
\text { Difference }\end{array}$} & & & \\
\hline & & & & & Lower & Upper & & & \\
\hline $\begin{array}{l}\text { huma } \\
\text { nities }\end{array}$ & $\begin{array}{l}\text { pretest } \\
\text { - } \\
\text { posttest }\end{array}$ & -3.800 & 1.48842 & .23534 & -4.2760 & -3.3239 & -16.147 & 39 & .000 \\
\hline
\end{tabular}

The obtained results, presented in table 4.5, show that there was a significant difference between pre-test $(\mathrm{M}=9.075, \mathrm{SD}=2.346)$ and post-test $(\mathrm{M}=12.875, \mathrm{SD}$ $=2.700), \mathrm{t}(39)=16.147, \mathrm{p} \leq .000$ (two-tailed). The mean increase of the obtained scores was 3.800 with a $95 \%$ confidence interval ranging from 4.276 to 3.323 . The eta squared statistic (0.49) indicated a moderate effect size.

Moreover, the performances of humanity and science groups in the posttest were also compared conducting an independent-samples t-test. This analysis was conducted to find out the difference in the performance of the group with a higher rate of improvement. Table 4.6 reveals the descriptive statistics on the performance of each group in post-test.

Table 4.6: Descriptive Statistics of Humanity and Science Groups in Post-test

\begin{tabular}{|l|l|l|l|l|l|}
\hline & \multicolumn{1}{|c|}{ groups } & \multicolumn{1}{|c|}{ N } & Mean & $\begin{array}{c}\text { Std. } \\
\text { deviation }\end{array}$ & $\begin{array}{c}\text { Std. Error } \\
\text { mean }\end{array}$ \\
\hline $\begin{array}{l}\text { Post } \\
\text { Test }\end{array}$ & humanities & 40 & 12.8750 & 2.70031 & .42696 \\
\cline { 2 - 6 } & sciences & 40 & 14.2750 & 2.64078 & .41754 \\
\hline
\end{tabular}

Table 4.7 shows the numerical statistics on the independent samples T-test for the post-test scores and significant difference in performance of the two groups.

Table 4.7: Independent Samples T-test for Post-Test Scores

\begin{tabular}{|c|c|c|c|c|c|c|c|c|c|c|}
\hline & & \multicolumn{2}{|c|}{$\begin{array}{c}\text { Levene's } \\
\text { Test for } \\
\text { Equality of } \\
\text { Variances } \\
\end{array}$} & \multicolumn{7}{|c|}{ t-test for Equality of Means } \\
\hline & & $\mathbf{F}$ & Sig. & \multirow[t]{2}{*}{$\mathbf{t}$} & \multirow[t]{2}{*}{ df } & \multirow{2}{*}{$\begin{array}{l}\text { Sig. } \\
(2- \\
\text { taile } \\
\text { d) }\end{array}$} & \multirow[t]{2}{*}{$\begin{array}{l}\text { Mean } \\
\text { Differe } \\
\text { nce }\end{array}$} & \multirow{2}{*}{$\begin{array}{l}\text { Std. } \\
\text { Error } \\
\text { Differe } \\
\text { nce }\end{array}$} & \multicolumn{2}{|c|}{$\begin{array}{l}95 \% \text { Confidence } \\
\text { Interval of the } \\
\text { Difference }\end{array}$} \\
\hline & & & & & & & & & Lower & Upper \\
\hline \multirow[t]{2}{*}{$\begin{array}{l}\text { Post } \\
\text { test }\end{array}$} & $\begin{array}{l}\text { Equal } \\
\text { variances } \\
\text { assumed }\end{array}$ & .073 & .788 & -2.344 & 78 & .002 & -1.4000 & .59719 & -2.5889 & -.21109 \\
\hline & $\begin{array}{l}\text { Equal } \\
\text { variances } \\
\text { not } \\
\text { assumed }\end{array}$ & & & -2.344 & 77.961 & .002 & -1.4000 & .59719 & -2.5889 & -.21108 \\
\hline
\end{tabular}


As the statistical results in table 4.7 show, there was a significant difference in posttest scores of the science group $(\mathrm{M}=14.275, \mathrm{SD}=2.640)$ and the ones in humanity group $(\mathrm{M}=12.875, \mathrm{SD}=2.700), \mathrm{t}(78)=2.344, \mathrm{p} \leq .0005$ (two-tailed). Moreover, the magnitude of the difference in the mean scores (mean difference $=$ 1.400 ) was moderate (eta squared $=0.41$ ).

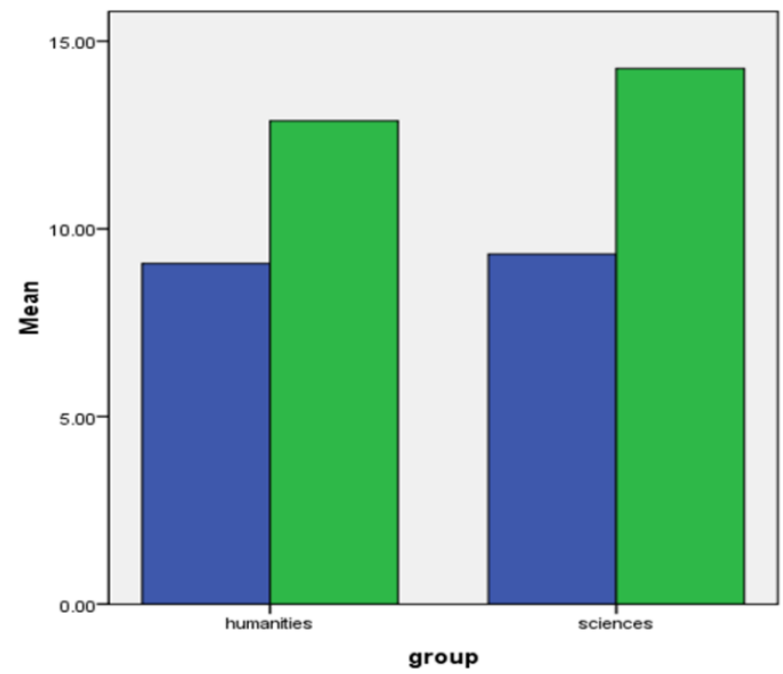

吕pretest

Figure 4.1: Bar Graph for the Difference Between the Two Groups in Pre-Test and Post-Test

Figure 4.1 clearly demonstrates the existing difference in reading comprehension of humanity and science groups in pre-test and post-test. The results of the study showed that although both groups had similar reading ability at the beginning of the study; however, the learners participating in the science group gained higher scores in the reading comprehension post-test comparing to the learners in the humanity group.

\section{DISCUSSION AND CONCLUSION}

As stated in the previous sections, the principal interest of the current study was to figure out the effect of the summarizing strategy on Iranian EFL learners' reading comprehension. The results advocate the idea suggested by Soleimani and Hajghani (2013) noting that successful use of a reading strategy depends on different factors such as the knowledge of how to utilize that strategy which was provided through a strategy based instruction. As Novak (2010) argued, "the central purpose of education is to empower learners to take charge of their own meaning making" and learning strategies such as summarizing strategy are powerful tools to serve such requirements. The results of the study showed that having achieved an awareness of summarizing strategy, students can have a better command of a variety of practices that they can use for successful summaries of the passages. The findings of this study in line with the other researchers (Aghaei, \& Zhang, 2012; Al-Nujaidi, 2003; Al-Seweed, 2000; Jitendraa, et al., 2006; Karbalaei \& Rajyashree, 2010; Pakzadian 
\& Eslami Rasekh, 2012; Shang, 2010; Sheorey et al., 2008;) showed that reading comprehension tests can help the students to follow the steps of the summarizing process to identify topics, main ideas, and details, and to write summaries. It can be concluded that when students are exposed to summarizing strategy, they become aware of the processes that can be applied in better understanding the reading passages and they can view the passage as a whole unit in which knowledge of the parts can be attained by paying attention to the preceding and following sections of the passage. Moreover, considering the literature, it should be mentioned that no studies have been conducted in the Iranian context comparing the effect of a reading strategy on reading comprehension of the students studying in different fields of study. Therefore, the recent study was innovative in this regard.

According to the findings, sufficient time is needed to develop particular reading skills and strategies such as summarizing strategy and indeed encourage content reading intending to make students ready for autonomous reading and understanding (Khoshsima \& Rezaeian Tiyar, 2014). Through the summarizing strategy instruction, teachers can identify students' weaknesses in reading comprehension and make the essential efforts to solve their comprehension problems as much as possible. Besides, emphasizing the significance of individuals' differences and their various learning styles, this study can be an encouragement for high school teachers to provide opportunities for Iranian EFL learners studying in different fields to become acquainted with summarizing strategies and help them match their learning styles with this strategy. Finally, the findings obtained from this study imply that teachers need to get familiar with new techniques of commenting on the performance of EFL learners. By identifying the problems and their sources, teachers can offer remedial strategies and tasks in order to rectify the EFL learners' difficulties and errors. Moreover, it would be reasonable to allocate some time training teachers and educators on different functions (positive and negative points) of each of these strategies. Their performance on posttest showed significant results for using this strategy and advocated the importance of students' strategy learning.

\section{REFERENCES}

Alderson, R.C. (2000). Assessing reading. New York: Cambridge University Press.

Aghaei, R., \& Zhang, L. J. (2012). Effects of explicit instruction in cognitive and metacognitive reading strategies on Iranian EFL students' reading performance and strategy transfer. Instructional Science, 40(6), 1063-1081.

Al-Nujaidi, A. (2003). The relationship between vocabulary size, reading strategies, and reading comprehension of EFL learners in Saudi Arabia. Unpublished doctoral dissertation, Oklahoma State University-Stillwat.

Al-Seweed, M. (2000). The effects of proficiency and training on the word-solving strategies of Arab EFL readers. Unpublished doctoral dissertation, University of Essex, UK.

Bagheri, Z. (2012). Teaching reading comprehension strategies to Iranian EFL preuniversity students. The Journal pf Teaching Foreign Language Skills, 4(1), 107-138.

Indonesian Journal of EFL and Linguistics, Vol. 2 (1), 2017 
Broukal, M. (2002). Reading for the TOEFL Test. Lawrenceville, NJ: Peterson`s Guide.

Chang, J. (2000). Learning disabilities. USA: Houghton Mifflin Company.

Damayanti, I. L. (2017). From Storytelling to Story Writing: the Implementation of Reading to Learn (R2L) Pedagogy to Teach English as A Foreign Language in Indonesia. Indonesian Journal of Applied Linguistics. Vol 6, No 2 (2017)

Davis, D. S. (2010). A meta-analysis of comprehension strategy instruction for upper elementary and middle school students. Unpublished Ph.D. dissertation. Vanderbilt University, America.

Deshpande, S. K. (2016). Activating Background Knowledge: An Effective Strategy to Develop Reading Comprehension Skills. JELTL (Journal of English Language Teaching and Linguistics), 1(3), 2016

Garner, R. (1987). Metacognition and reading comprehension. Norwood, NJ: Ablex.

Hsu, L. (2000). Increasing higher level language skills to improve reading comprehension. Focus on Exceptional Children, 44 (3), 1-19.

Hung, S. \& Tzeng, B. (2000). The value of English picture story books. ELT Journal, 62(1), 47-55.

Jitendraa, A. K., Colea, C. L., Hoppesa, M. K., \& Wilsona, B. (2006). Effects of a direct instruction main summarization program and self-Monitoring on reading comprehension of middle school students with learning disabilities. System, 379-396. doi:10.1080/1057356980140403

Kamil, M. L. (2004). Vocabulary and comprehension instruction: Summary and implications of the national reading panel findings. Academic Exchange Quarterly, 12, 113-122.

Karbalaei, A., \& Rajyashree, K.S. (2010). The impact of summarization strategy training on university ESL learners' reading comprehension. The International Journal of Language Society and Culture, 30, 41-53. URL: www.educ.utas.edu.au/users/tle/JOURNAL/

Khoshsima, H., \& Rezaeian Tiyar, F. (2014). The Effect of summarizing strategy on reading comprehension of Iranian intermediate EFL learners. International Journal of Language and Linguistics. 2(3), 134-139. doi: $10.11648 / \mathrm{j} . \mathrm{ij} 11.20140203 .11$

Madkhali, S. (2005). Effects of training ESL Saudi female students on some reading strategies. Unpublished dissertation, Ball State University-Muncie.

McNamara, D. (Ed.). (2007). Reading comprehension strategies: Theories, intervention, and technologies. Mahwah, NJ: Lawrence Erlbaum Associates, Inc.

Munsakorn, N. (2012). Awareness of reading strategies among EFL learners at Bangkok university. International Journal of Social and Human Sciences, 6, 497-500.

Mushait, S. (2004). The relationship of L1 reading and L2 language proficiency with the L2 reading comprehension and strategies of Saudi EFL university students. Unpublished doctoral dissertation, University of Essex, UK. 
Nation, K., \& Angell, P. (2006). Learning to read and learning to comprehend. London Review of Education, 4(1), 77-87.

Novak, J. D. (2010). Learning, creating, and using knowledge: Concept maps as facilitative tools in schools and corporations. Journal of e-Learning and Knowledge Society, 6(3), 21-30.

Nurhayati, D.A.W. (2014). Using Picture Series to Inspire Reading Comprehension for the Second Semester Students of English Department of IAIN Tulungagung. Dinamika Ilmu, Vol 14 No 2, 2014.

Pakzadian, M., \& Eslami Rasekh, A. (2012). The effects of using summarization strategies on Iranian EFL learners' reading comprehension. English Linguistics Research, 1 (1), 118-125. doi:10.5430/elr.v1n1p118. Retrieved from http://dx.doi.org/10.5430/elr.v1n1p118.

Richards, J. C. \& Renandya, W. A. (2001). Methodology in language teaching: an anthology of current practice. New York: Cambridge.

Roohani, A., Jafarpour, A., Zarei, S. (2015). Effects of Visualisation and Advance Organisers in Reading Multimedia-Based Texts. 3L: Language, Linguistics, Literature ${ }^{\circledR}$, Vol 21, No 2 (2015)

Shang, H.-F. (2010). Reading strategy use, self-efficacy, and EFL reading comprehension. Asian EFL Journal, 12(2), 18-42.

Sheorey, R., Kamimura, Y., \& Freiermuth, M. (2008). Reading strategies of firstand second language learners. Norwood, MA: Christopher-Gordon.

Soleimani, H., \& Hajghani, S. (2013). The effect of teaching reading comprehension strategies on Iranian EFL pre-university students' reading comprehension ability. International Journal of Applied and Basic Sciences, 5(5), 594-600.

Susser, B., \& Robb, T. (1990). Extensive reading instruction: Research and procedure. JALT Journal, 12, 161-185.

Teng, Feng. (2016). The Effects of Word Exposure Frequency on Incidental Learning of the Depth of Vocabulary Knowledge. GEMA Online ${ }^{\circledR}$ Journal of Language Studies, Vol 16, No 3 (2016)

Wallace, C. (1992). Reading. Oxford: Oxford University Press. 